\title{
Effects of Sulla forage (Sulla coronarium L.) on the oxidative status and milk polyphenol content in goats
}

\author{
A. Di Trana, ${ }^{* 1}$ A. Bonanno,† S. Cecchini,‡ D. Giorgio, ${ }^{*}$ A. Di Grigoli, $†$ and S. Claps $\S$ \\ *Scuola di Scienze Agrarie, Forestali, Alimentari ed Ambientali, Università degli Studi della Basilicata, Viale dell'Ateneo Lucano 10 , \\ 85100 Potenza, Italy \\ †Dipartimento Scienze Agrarie e Forestali, Università degli Studi di Palermo, Viale delle Scienze, 90128 Palermo, Italy \\ ¥Dipartimento di Scienze, Università degli Studi della Basilicata, Viale dell'Ateneo Lucano 10, 85100 Potenza, Italy \\ §CRA-ZOE, Unità di ricerca per la zootecnia estensiva,Via Appia, Bella Scalo 85054, Muro Lucano, Italy
}

\section{ABSTRACT}

Twelve milking Girgentana goats were allocated into 3 groups and fed 3 diets ad libitum in a $3 \times 3$ Latin square design with 3 periods. The diets were Sulla fresh forage ad libitum (SUL), Sulla fresh forage ad libitum and $800 \mathrm{~g} / \mathrm{d}$ of barley meal (SULB), and mixed hay ad libitum and $800 \mathrm{~g} / \mathrm{d}$ of barley meal (HB). Changes were observed in total polyphenol intake, plasma oxidative status, plasma polyphenol content, metabolic status, milk polyphenol content, and total antioxidant capacity. The fresh forage diets (SUL and SULB) increased dry matter, total polyphenol, nontannic polyphenol and tannin intakes, and the milk total protein, casein, milk total polyphenols, and milk free polyphenols compared with the HB diet. The intake of condensed tannins was higher in the SUL than in the $\mathrm{HB}$ group, and an intermediate value was recorded for the SULB group. Plasma from the SUL- and SULBfed goats exhibited greater total antioxidant capacity and greater total polyphenol and free polyphenol levels compared with the plasma from the HB group. Positive correlations between plasma total antioxidant capacity and condensed tannins intake $(\mathrm{r}=0.43)$, plasma total polyphenol and total polyphenol intake $(\mathrm{r}=0.61)$, and plasma free polyphenol and milk total polyphenols ( $\mathrm{r}$ $=0.38$ ) were observed. The correlation between milk free polyphenols and whey total antioxidant capacity $(\mathrm{r}=0.42)$ highlights the role of free polyphenols in the determination of the antioxidant activity of milk. These results indicate that Sulla fresh forage exerts an antioxidant activity due to its secondary compounds that provide additional antioxidant value and that Sulla forage appears to be a promising strategy for improving product quality.

Key words: oxidative status, milk, Sulla forage, polyphenol

Received May 27, 2014.

Accepted September 29, 2014.

${ }^{1}$ Corresponding author: adriana.ditrana@unibas.it

\section{INTRODUCTION}

Reactive oxygen species (ROS) are the result of catabolic processes in living beings and are primarily produced in the mitochondrial electron transport chain (Ames et al., 1995). However, several biochemical pathways are responsible for ROS production, such as the respiratory burst during phagocytosis, which causes the production of potent oxidant bactericidal substances. Because of their nonspecific activities, ROS may be responsible for oxidizing self-biomolecules, and lipids are particularly susceptible to such molecules (Miller et al., 1993).

To counteract ROS activity, aerobic organisms possess an effective antioxidant defense system that in part depends on the dietary supply of antioxidants (Bendich, 1993). According to the literature, when an imbalance between oxidants and antioxidants occurs, the organism experiences a condition called oxidative stress, which can cause oxidative damage if cellular biomolecules undergo oxidative modifications (Celi, 2011). With regard to farm animals, oxidative stress has been shown to result from both disease and from some physiological stages, such as the peripartum period of dairy cows and dairy goats. Moreover, the balance between pro-oxidants and the antioxidant system is influenced by nutrition, season, body condition at calving, heat stress, and milk yield (Castillo et al., 2006; Di Trana et al., 2006; Celi, 2011).

A natural and feasible option for promoting a positive antioxidant balance, improving animal performance, and ensuring that animal products are safe for human consumption is the use of forages that containing bioactive compounds. This approach is a new goal for sustainable and environmentally oriented agriculture. The uses of plants, plant extracts, or natural plant compounds of several plant species that have antioxidant activities that result from several compounds, such as polyphenols, are well known (Makkar et al., 2007; Celi and Raadsma, 2010; Luciano et al., 2011).

In a previous study that examined the green borage plant (Borago officinalis L.) and hawthorn (Crataegus 
oxyacantha L.), De Feo et al. (2006) speculated about the relationship between the forage intake of green plants and the levels of antioxidant compounds in goat milk. Effects of feeding systems and the tannin contents of the diet on the antioxidant status of different biological samples were observed by Moñino et al. (2008) in lamb muscle as a consequence of the consumption of milk from ewes that were fed a rosemary extract. Furthermore, Hilario et al. (2010) showed that feeding system, grazing management, and fresh forage can improve the profile of bioactive compounds, such as antioxidants, within goat cheese. The dietary administration of polyphenols and tannin-rich plants and plant extracts has been shown to improve the oxidative stability of chicken, rat, and ewe meat (Larraín et al., 2007; Nieto et al., 2010). Luciano et al. (2011) found higher muscle antioxidant capacities in lambs when the animals received a concentrate to which a commercially available tannin-rich quebracho (Schinopsis lorentzii) extract was added. Recent studies have shown that tannins have antioxidant effects in vivo in different animal tissues. López-Andrés et al. (2013) reported greater antioxidant capacities of the liver tissue and blood plasma of lambs fed with a supplemented quebracho diet containing $6.4 \%$ tannins. According to those authors, the antioxidant capacities of the tissues can be detected only when samples are not purified using solid-phase extraction.

Among the plant species that are used in ruminant feed in the Mediterranean area, Sulla (Sulla coronarium L.), which is a short-lived perennial legume, plays a key role in the cereal-based systems that are used in semiarid regions. In these regions, Sulla is extensively grown as a 2-yr forage crop that is primarily used for grazing or silage and hay production. Sulla is characterized by a high protein content, a relatively high ratio of components that are readily fermentable to structural carbohydrates, interesting content of total phenolic and nontannic phenolic compounds, and a moderate concentration of condensed tannins (Burke et al., 2004; Piluzza and Bullitta, 2010). In Mediterranean environments, the condensed tannins content of Sulla is highly variable and ranges from 8 to $50 \mathrm{~g} / \mathrm{kg}$ of the whole plant DM depending on the environment, growth stage, and genotype (Amato et al., 2005). Variations in total phenolic, nontannic phenolic, and condensed tannins contents of Sulla have been observed to depend on the phenological phase and plant organs. Indeed, the leaf blades are the organs with the highest content of phenolic compounds (Piluzza and Bullitta, 2010). The chemical-bromatological composition and phenolic compound and CT contents of Sulla forage have been shown to be advantageous for ruminants improving their performances (Bonanno et al., 2007a,b, 2011; Molle et al., 2009) and the quality of dairy products (Addis et al., 2005; Cabiddu et al., 2009). The positive milk performance responses exhibited by dairy sheep that are grazed on Sulla compared with those of Mediterranean sheep in grass-based pastures are relevant (Molle et al., 2008). For example, Sulla forage consumption reduces gastrointestinal nematode parasitism in sheep. These beneficial effects have been attributed to the ability of Sulla to enhance nitrogen utilization in the gastrointestinal tract due to the abilities of dietary protein bound to condensed tannins to effectively bypass the rumen (Min et al., 2003) and increase the resistance and resilience to gastrointestinal parasites (Hoste et al., 2006).

However, the effect of Sulla forage in dairy goats has not yet been studied in terms of the roles and activities of the bioactive compounds of Sulla. Thus, the hypothesis of the present study is that feeding regimens with Sulla forage will improve antioxidant or oxidant balance in dairy goats and improve milk quality. To test this hypothesis, changes in oxidant and antioxidant substances were measured in an animal system as total oxidants, total antioxidant capacity, total polyphenols, glutathione peroxidase, and superoxide dismutase activities in the blood, and changes in total polyphenols, free polyphenols, and total antioxidant capacities in the milk of goats fed 3 different diets. Moreover, the metabolic profiles of the animals were monitored to evaluate their nutritional status.

\section{MATERIALS AND METHODS}

\section{Animals, Location, and Experimental Design}

The study was conducted on a private farm located in Sicily (Santa Margherita Belice, Agrigento, Italy) from March to May over a period of 11 wk. Twelve milking Girgentana goats were used. For the entire experimental period, the goats were individually housed in large pens inside a shed. After a 2 -wk period of adaptation to the new housing conditions, the goats were homogeneously allocated to 1 of 3 different groups that received different diets based on live weight (37.2 $\pm 3.5 \mathrm{~kg})$ and DIM $(86 \pm 19)$ according to a $3 \times 3$ Latin square design with 3 periods. Each period was composed of $14 \mathrm{~d}$ for adaptation to the diets and $7 \mathrm{~d}$ for data and sample collection.

The 3 experimental diets were Sulla fresh forage ad libitum (SUL), Sulla fresh forage ad libitum and 800 g/d of barley meal (SULB), and mixed hay ad libitum and $800 \mathrm{~g} / \mathrm{d}$ of barley meal (HB). These diets reflect the common feeding regimens of grazing goats in Mediterranean environments according to the herbage allowance at pasture. The chemical compositions of the offered feeds are shown in Table 1. Sulla fresh forage 
Table 1. Chemical composition of ingested feed

\begin{tabular}{|c|c|c|c|}
\hline Feed ( $\mathrm{g} / \mathrm{kg}$ of DM, unless otherwise noted) & Sulla coronarium & Hay & Barley \\
\hline $\mathrm{DM}(\mathrm{g} / \mathrm{kg})$ & 182 & 873 & 879 \\
\hline $\mathrm{CP}$ & 186 & 129 & 111 \\
\hline Ether extract & 32 & 13 & 22 \\
\hline $\mathrm{NDF}$ & 320 & 427 & 197 \\
\hline $\mathrm{ADF}$ & 267 & 374 & 88 \\
\hline ADL & 50 & 73 & 13 \\
\hline $\mathrm{NFC}^{1}$ & 370 & 283 & 641 \\
\hline Ash & 93 & 146 & 29 \\
\hline Total polyphenols (g of $\mathrm{GAE}^{2} / \mathrm{kg}$ of $\mathrm{DM}$ ) & 5.10 & 1.28 & 0.43 \\
\hline Nontannic polyphenols ( $\mathrm{g}$ of $\mathrm{GAE} / \mathrm{kg}$ of $\mathrm{DM}$ ) & 2.04 & 1.03 & 0.41 \\
\hline Tannins ( $\mathrm{g}$ of $\mathrm{GAE} / \mathrm{kg}$ of $\mathrm{DM}$ ) & 3.02 & 0.25 & 0.02 \\
\hline Condensed tannins ( $\mathrm{g}$ of $\mathrm{DE}^{3} / \mathrm{kg}$ of $\left.\mathrm{DM}\right)$ & 19.90 & 2.00 & 0.00 \\
\hline
\end{tabular}

was mowed daily in the morning, roughly cut, and supplied to the goats in feeding troughs twice daily at 1000 and $1700 \mathrm{~h}$. Hay was a mixture of berseem clover and spontaneous grasses, mainly Lolium spp. and Phalaris spp., constantly available to the goats, and the barley meal was divided into 2 meals.

\section{Sample Collection}

During the sampling week of each period, the offered and refused forage and barley of each goat were weighed daily and sampled twice to estimate the amount and quality of the ingested feeds. At the beginning and end of each experimental period, all goats were weighed, examined to determine their BCS by the same operator using a 6-point scale (Santucci et al., 1991), and submitted to blood sampling in the morning via jugular venipuncture. Each blood sample was divided into 2 Vacutainer (Becton, Dickinson and Company, Franklin Lakes, NJ) tubes; 1 tube contained lithium heparin and was immediately placed on ice and the other did not contain any anticoagulant. Plasma was obtained by centrifugation at $1,400 \times g$ for $10 \mathrm{~min}$ at $4^{\circ} \mathrm{C}$. The serum samples were obtained by maintaining the blood samples at room temperature until clotting occurred and then centrifuging the samples. The plasma and serum samples were stored at $-80^{\circ} \mathrm{C}$ until the time of analysis. Erythrocytes were obtained by centrifuging 0.5 $\mathrm{mL}$ of blood at $1,400 \times \mathrm{g}$ for $10 \mathrm{~min}$ at $4^{\circ} \mathrm{C}$ and washing 4 times with $3 \mathrm{~mL} 0.9 \% \mathrm{NaCl}$ solution. After the final wash, the red blood cells were lysed by hypotonic shock using $2 \mathrm{~mL}$ of redistilled water. The hemolysates were mixed and left at $4^{\circ} \mathrm{C}$ for 15 min. Individual milk yields were recorded daily at the morning and evening milkings and were sampled 3 times during the sampling week of each period.

\section{Analytical Methods}

The Sulla forage, mixed hay, and barley samples were analyzed for determinations of DM, CP, ether extract, ash (AOAC International, 1995), NDF, ADF, and ADL (Van Soest et al., 1991). Nonfiber carbohydrate content was calculated as NFC $=100-(\% \mathrm{NDF}+\% \mathrm{CP}+\%$ ether extract $+\%$ ash).

Total, nontannic, and tannic polyphenol contents were analyzed in the water extracts of the freeze-dried samples of the Sulla forage, hay, and barley (Table 1). To obtain water extracts, the samples were macerated in sterilized distilled water $(10 \% \mathrm{wt} / \mathrm{vol})$ at room temperature $\left(20^{\circ} \mathrm{C}\right)$ for $48 \mathrm{~h}$ under gentle shaking. The obtained macerates were centrifuged $(3,000 \times g$ for 20 min at $4^{\circ} \mathrm{C}$ ), and the supernatants were then collected and filtered progressively up to $0.45 \mu \mathrm{m}$ before concentrating them using a lyophilizer. Finally, the percentage yields of the extracts were computed, and the samples were resuspended in distilled water at a concentration of $1 \mathrm{mg} / \mathrm{mL}$ for phytochemical analyses. The total, nontannic, and tannic polyphenol contents were determined using the Folin-Ciocalteu method as described by FAO/IAEA (2000) and are expressed as gallic acid equivalents (GAE; $\mu \mathrm{g} / \mathrm{mg}$ of sample). Condensed tannin (CT) content, expressed as delphinidin equivalents (Tava et al., 2005), was measured in the freeze-dried samples of Sulla forage using the butanol-HCl method (Porter et al., 1986).

Plasma oxidants and total antioxidant capacity (TAC) were measured as reactive oxygen metabolites (ROM), mainly hydroperoxides generated by the oxidation of biomolecules, and biological antioxidant potential, measuring the plasma sample capacity to reduce iron from ferric $\left(\mathrm{Fe}^{3+}\right)$ to ferrous $\left(\mathrm{Fe}^{2+}\right)$ form, using 2 different kits provided by Diacron (Grosseto, 
Italy). The experimental data are expressed as Unit Carr (U. Carr) and reduced iron $(\mu \mathrm{Eq} / \mathrm{L})$, respectively. Glutathione peroxidase (GSH-Px) activity as evaluated in the whole blood and superoxide dismutase (SOD) activity as evaluated in the erythrocyte lysates were analyzed by kinetic methods with commercial kits according to the manufacturer's instructions (Randox Laboratories, Crumlin, Co. Antrim, UK).

Plasma total polyphenol (PTP) content was determined by the Folin-Ciocalteu method (ISO, 2005) following the procedures of acid extraction or hydrolysis and protein precipitation described by Serafini et al. (1998). Plasma free polyphenol (PFreeP) content was determined by the Folin-Ciocalteu method after direct protein precipitation according to the method suggested by Santiago-Arteche et al. (2012). The PTP and PFreeP contents of the plasma samples are expressed as $\operatorname{GAE}(\mu \mathrm{g} / \mathrm{mL})$.

The metabolic and hormonal profiles of goats were measured. A TARGA model 2000 (Technology Advanced Random Generation Analyzer, Biotecnica Instruments, Roma, Italy) automated analyzer was used to determine the glucose and urea levels (Mercury, Riardo, Italy) in the plasma samples. Nonesterified fatty acids and BHBA were analyzed using FA 115 and Ranbut commercial kits, respectively (Randox Laboratories) following the manufacturer's instructions. Insulin-like growth factor-1 (IGF-1 600; DRG Diagnostics, Marburg, Germany) levels were determined using commercially available ELISA kits.

Individual milk samples were analyzed for fat, lactose, protein, and casein via the infrared method (Combi-foss 6000, Foss Electric, Hillerød, Denmark), and urea was analyzed using a differential $\mathrm{pH}$ meter (CL-10 Plus, Eurochem, Ardea, Rome, Italy). Fat- and protein-corrected milk (FPCM) at $3.5 \%$ fat and $3.5 \%$ protein was calculated as FPCM g/d $=(12.82 \times \mathrm{kg}$ of fat $)+(7.13 \times \mathrm{kg}$ of protein $)+(0.323 \times \mathrm{kg}$ of milk $)$ (Hall, 2004).

Milk total polyphenol (MTP) and milk free polyphenol (MFreeP) contents are expressed as GAE $(\mu \mathrm{g} /$ $\mathrm{mL}$ ) and were determined as described for the plasma samples. Whey total antioxidant capacity (WTAC) was measured according to the suggestions of Chen et al. (2003) using the ferric-reducing antioxidant power assay as indicated by Benzie and Strain (1996) and are expressed as ferrous sulfate $\cdot 7 \mathrm{H}_{2} \mathrm{O}(\mu M)$.

\section{Statistical Analyses}

The statistical analyses were performed using the MIXED procedure of SYSTAT 13 (SYSTAT Software Inc., Chicago, IL). The experimental feeding regimen (SUL, SULB, and HB) and period $(1,2,3)$ were fixed factors, and the specific goat was considered a random factor. Prior to the analysis, the normalities of the distributions of the variables were assessed, and the data were log-transformed when necessary (i.e., the GSHPx, IGF-1, and TAC data). The differences between means were tested with Fisher's LSD test. Significance was declared at $P \leq 0.05$, and tendencies were declared at $0.05<P \leq 0.10$. Pearson correlation coefficients were calculated between the variables measured in this study.

\section{RESULTS AND DISCUSSION}

\section{Feed Intake}

The live weights and BCS of the goats in all groups were not affected by the feeding regimen (data not shown). Feeding regimen significantly affected DM $(P$ $\leq 0.05), \mathrm{CP}, \mathrm{NDF}$, total polyphenol (TP), nontannic polyphenols (NTP), tannins (T), and CT $(P \leq$ 0.001) intake (Table 2). Goats fed Sulla fresh forage, compared with the dry diet group, exhibited increased DMI, regardless of barley energy supplementation. This positive effect of Sulla forage on the voluntary feed intake of goats observed in our experiment confirms previous findings from milking sheep (Molle et al., 2003; Bonanno et al., 2007b) and lambs (Bonanno et al., 2011) and can be linked to its more favorable chemical composition. Indeed, compared with hay, the ingested Sulla forage showed high CP content, low NDF and ADL contents, and a high NSC-to-NDF ratio (Table 1), characteristics that generally result in a faster rate of degradation in the rumen and subsequent faster outflow to the intestine which favors the increase of DMI (Burke et al., 2004; Avondo et al., 2008).

The CP, NDF, and CT intakes, reflecting the differences in DMI and chemical composition among diets, were highest $(P \leq 0.05)$ in the SUL group than in the other groups. The TP, NTP and T intakes were higher in the SUL- and SULB-fed goats than in the HB-fed goats, whereas the $\mathrm{CT}$ intake increased with increasing levels of ingested fresh forage. The lower TP, NTP, T, and $\mathrm{CT}$ intakes $(P \leq 0.05)$ of the HB-fed goats were strongly influenced by the lower DMI values and polyphenol contents of hay and barley.

\section{Plasma Oxidant-Antioxidant Content}

Data concerning the effects of feeding regimen on oxidative status biomarkers and PTP contents are reported in Table 3. Diet significantly influenced plasma TAC $(P \leq 0.01)$ and PTP $(P \leq 0.05)$ concentrations; both of these variables were higher in the SUL and SULB groups than in the HB group. The TAC, which 
Table 2. Least squares means of daily intake of nutrients according to feeding regimens

\begin{tabular}{|c|c|c|c|c|c|}
\hline \multirow[b]{2}{*}{ Item } & \multicolumn{3}{|c|}{ Feeding regimen $(\mathrm{FR})^{1}$} & \multirow[b]{2}{*}{ SEM } & \multirow{2}{*}{$\frac{\text { Significance }}{\text { FR }}$} \\
\hline & HB & SUL & SULB & & \\
\hline DMI $(g / d)$ & $1,651^{\mathrm{b}}$ & $1,820^{\mathrm{a}}$ & $1,807^{\mathrm{a}}$ & 76 & $*$ \\
\hline $\mathrm{CP}$ intake $(\mathrm{g} / \mathrm{d})$ & $203^{\mathrm{c}}$ & $321^{\mathrm{a}}$ & $290^{\mathrm{b}}$ & 15 & $* * *$ \\
\hline NDF intake $(\mathrm{g} / \mathrm{d})$ & $539^{\mathrm{b}}$ & $632^{\mathrm{a}}$ & $483^{\mathrm{c}}$ & 37 & *** \\
\hline Total polyphenols intake ( $\mathrm{g}$ of $\mathrm{GAE} / \mathrm{d})^{2}$ & $1.53^{\mathrm{b}}$ & $9.20^{\mathrm{a}}$ & $8.88^{\mathrm{a}}$ & 0.62 & $* * *$ \\
\hline Nontannic polyphenols intake ( $\mathrm{g}$ of GAE/d) & $1.26^{\mathrm{b}}$ & $3.72^{\mathrm{a}}$ & $3.24^{\mathrm{a}}$ & 0.33 & $* * *$ \\
\hline Tannins intake ( $\mathrm{g}$ of GAE/d) & $0.26^{\mathrm{b}}$ & $5.48^{\mathrm{a}}$ & $5.64^{\mathrm{a}}$ & 0.31 & $* * *$ \\
\hline Condensed tannins intake $(\mathrm{g} \text { of } \mathrm{DE} / \mathrm{d})^{3}$ & $3.50^{\mathrm{c}}$ & $47.20^{\mathrm{a}}$ & $35.60^{\mathrm{b}}$ & 1.60 & $* * *$ \\
\hline
\end{tabular}

${ }^{a-c}$ Values within a row without a common superscript letter are significantly different $(P \leq 0.05)$.

${ }^{1} \mathrm{HB}=$ mixed hay plus $800 \mathrm{~g} / \mathrm{d}$ of barley meal; SUL = Sulla fresh forage; SULB = Sulla fresh forage plus 800 $\mathrm{g} / \mathrm{d}$ of barley meal.

${ }^{2} \mathrm{GAE}=$ gallic acid equivalent.

${ }^{3} \mathrm{DE}=$ delphinidin equivalent.

$* P \leq 0.05 ;{ }^{* * *} P \leq 0.001$.

was measured as the biological antioxidant potential, rose from 2,366 to 3,005 and $3,075 \mu \mathrm{Eq} / \mathrm{L}$ in the $\mathrm{HB}$, SULB, and SUL groups, respectively. A lower PTP value was detected in the HB-fed goats compared with the values of the SUL- and SULB-fed groups $(294,304$, and $310 \mu \mathrm{g} / \mathrm{mL}$ of GAE, respectively). No significant difference between the SUL and SULB groups was observed.

The literature provides evidence that body condition at calving, milk yield, grazing season, and levels of starch affect blood oxidative status in ruminants (Celi,
2011). Particularly, Gabai et al. (2004) observed that diet starch content may alter the control of oxidative stress in cows during early lactation. Pedernera et al. (2010) showed in cows with severe negative energy balance an indirect effect on the oxidative status. With regard to the effect of different dietary protein levels on oxidative status, Machín et al. (2004) showed that in high-protein diet-fed chicken the plasma uric acid concentration, the major end product of nitrogen metabolism in birds serving as useful antioxidant during long physical exercises, is increased and negatively cor-

Table 3. Least squares means of oxidative status biomarkers, plasma polyphenols, metabolic profile, and IGF-1 hormone

\begin{tabular}{|c|c|c|c|c|c|}
\hline \multirow[b]{2}{*}{ Item } & \multicolumn{3}{|c|}{ Feeding regimen $(\mathrm{FR})^{1}$} & \multirow[b]{2}{*}{ SEM } & \multirow{2}{*}{$\frac{\text { Significance }}{\text { FR }}$} \\
\hline & HB & SUL & SULB & & \\
\hline \multicolumn{6}{|l|}{ Oxidative status } \\
\hline Reactive oxygen metabolites (Unit Carr) & 81.79 & 64.29 & 83.09 & 11.91 & NS \\
\hline $\mathrm{TAC}^{2}(\mu \mathrm{Eq} / \mathrm{l})$ & $2,366^{\mathrm{b}}$ & $3,075^{\mathrm{a}}$ & $3,005^{\mathrm{a}}$ & 150 & $* *$ \\
\hline Glutathion peroxidase (Ln U/L of blood) & $4.18^{\mathrm{f}}$ & $4.16^{\mathrm{f}}$ & $4.23^{\mathrm{e}}$ & 0.02 & $\dagger$ \\
\hline Superoxide dismutase (U/mL of blood) & 236.81 & 234.86 & 240.88 & 17.43 & NS \\
\hline \multicolumn{6}{|l|}{ Plasma polyphenols } \\
\hline $\mathrm{PTP}^{3}\left(\mu \mathrm{g} / \mathrm{mL}\right.$ of $\left.\mathrm{GAE}^{4}\right)$ & $294.33^{\mathrm{b}}$ & $303.61^{\mathrm{a}}$ & $309.67^{\mathrm{a}}$ & 4.58 & * \\
\hline PFreeP $^{5}(\mu \mathrm{g} / \mathrm{mL}$ of GAE $)$ & $37.68^{\mathrm{f}}$ & $41.89^{\mathrm{e}}$ & $42.03^{\mathrm{e}}$ & 2.13 & $\dagger$ \\
\hline \multicolumn{6}{|l|}{ Metabolic and hormonal parameters } \\
\hline Glucose $(\mathrm{mmol} / \mathrm{L})$ & $2.54^{\mathrm{ef}}$ & $2.25^{\mathrm{f}}$ & $2.66^{\mathrm{e}}$ & 0.14 & $\dagger$ \\
\hline NEFA $(\mathrm{mmol} / \mathrm{L})$ & $0.226^{\mathrm{b}}$ & $0.389^{\mathrm{a}}$ & $0.207^{\mathrm{b}}$ & 0.030 & $* *$ \\
\hline $\mathrm{BHBA}(\mathrm{mmol} / \mathrm{L})$ & $0.446^{\mathrm{a}}$ & $0.276^{\mathrm{b}}$ & $0.486^{\mathrm{a}}$ & 0.044 & $* *$ \\
\hline IGF-1 (log ng/mL) & 2.07 & 2.04 & 2.11 & 0.03 & NS \\
\hline Urea $(\mathrm{mg} / 100 \mathrm{~mL})$ & 22.6 & 25.7 & 22.8 & 1.45 & NS \\
\hline \multicolumn{6}{|c|}{$\overline{\mathrm{a}, \mathrm{b}}$ Values within a row without a common superscript letter are significantly different $(P \leq 0.05)$. } \\
\hline \multicolumn{6}{|c|}{${ }_{\mathrm{e}, \mathrm{f}}^{\mathrm{V}}$ alues within a row without a common superscript letter are significantly different $(P \leq 0.10)$} \\
\hline \multicolumn{6}{|c|}{$\begin{array}{l}{ }^{1} \mathrm{HB}=\text { mixed hay plus } 800 \mathrm{~g} / \mathrm{d} \text { of barley meal; } \mathrm{SUL}=\text { sulla fresh forage; SULB }=\text { sulla fresh forage plus } 80 \mathrm{c} \\
\mathrm{g} / \mathrm{d} \text { of barley meal. }\end{array}$} \\
\hline \multirow{2}{*}{\multicolumn{6}{|c|}{$\begin{array}{l}{ }^{2} \mathrm{TAC}=\text { total antioxidant capacity; measured as biological antioxidant potential }(\mathrm{BAP}) \\
{ }^{3} \mathrm{PTP}=\text { plasma total polyphenols. }\end{array}$}} \\
\hline & & & & & \\
\hline \multicolumn{6}{|c|}{${ }^{4} \mathrm{GAE}=$ gallic acid equivalent. } \\
\hline \multicolumn{6}{|l|}{${ }^{5} \mathrm{PFreeP}=$ plasma free polyphenols. } \\
\hline$\dagger P \leq 0.10 ;{ }^{*} P \leq 0.05 ; *^{*} P \leq 0.01 ; \mathrm{NS}=1$ & & & & & \\
\hline
\end{tabular}


related with leukocyte oxidative activity. According to those authors, high dietary protein levels can reduce oxidative stress. On the contrary, Petzke et al. (2000) observed that long-term intake of high-protein diets did not lead to oxidative stress in adult rats. Celi and Robinson (2010) found that TAC is affected by dietary treatment with yerba mate (Ilex paraguariensis) in dairy calves, most likely because of the high polyphenol content of this herb. Conversely, according to Celi and Raadsma (2010), TAC does not seem to be influenced by dietary supplementation of dairy cows with yerba mate leaves, whereas the same variable is affected by the energy level of the feeding regimen of goats on the day of parturition (Celi et al., 2010).

Di Trana et al. (2006) observed that feeding regimens based on green forage improve the oxidative statuses of goats due to the elevated antioxidant contents of green grass; indeed, spring grazing has been shown to provide benefits to animal health due to the higher $\alpha$-tocopherol contents compared with summer grazing. In the current experiment, increases in TAC were observed in the samples from the SUL- and SULB-fed goats. These increases in plasma TAC might be related to the increases in TP and CT intakes (Table 2). The latter observation is supported by the positive correlation that was observed between plasma TAC and daily $\mathrm{CT}$ intake $(\mathrm{r}=0.43 ; P=0.01)$. This finding is consistent with the observation of Gladine et al. (2007), who reported a significant increase in plasma TAC in sheep following the direct ruminal administration of grape extracts, which are rich in CT. More recently, López-Andrés et al. (2013) showed that the plasma and livers of lambs that are fed a diet rich in quebracho tannins exhibit greater antioxidant capacities do the same tissues of lambs that are fed a control diet.

The bioavailabilities of phenolic compounds and tannins in ruminants have not been investigated extensively, and the results are often controversial. Makkar et al. (1995) reported that tannins are not degraded by ruminal microorganisms in vitro. Nevertheless, other authors have reported that ruminal microflora are able to degrade tannins into smaller phenolic compounds (Bhat et al., 1998), as evidenced by the poor recovery of polymeric proanthocyanidins after transit through the rumen (Terrill et al., 1994). In sheep and goats that have been offered a mixture of Digitaria decumbens and Desmodium intortum hay, CT levels are substantially reduced during metabolism in the gastrointestinal tract (Perez-Maldonado and Norton, 1996). Based on these results, it might be that $\mathrm{CT}$ may spare other antioxidants and thus indirectly increase antioxidant levels in other tissues, or CT may protect proteins, carbohydrates, and lipids from oxidative damage in the digestive tract during digestion (Marshall and Roberts,
1990). Hagerman et al. (1998) suggested that tannins or polymeric polyphenolics may be much more potent antioxidants than simple monomeric phenolic substances. A further study demonstrated that procyanidins, which are typical CT, are potent scavengers even when bound to proteins and that such complexes might act as a radical sink within the gastrointestinal tract (Riedl and Hagerman, 2001).

According to our results, the PTP contents were significantly $(P<0.05)$ increased in the SUL- and SULB-fed groups, and this difference reflected TP intake (Table 2); that is, a strong positive correlation was found between PTP and TP intake $(\mathrm{r}=0.61 ; P$ $=0.05$ ). Moreover, PFreeP (Table 3) increased in the fresh Sulla groups (SUL and SULB), although this difference was only a trend $(P=0.10)$.

The results of our study indicate that feeding regimens have weak effects on oxidative status biomarkers with the exception of TAC. The goats that were fed the SULB diet exhibited greater $(P \leq 0.05)$ milk yields (FPCM, Table 4), ROM values (NS), and GSH-Px ( $P$ $\leq 0.10)$ and SOD (NS; Table 3) activities compared with the HB- and SUL-fed groups. Unlike that observed in human species, for which reference values of total oxidants and antioxidants are reported (Cesarone et al., 1999; Dohi et al., 2005), the lack of the same reference values in ruminant species leads to difficulties in the interpretation of analytical data and in establishing if animals are experiencing oxidative stress. According to the literature, plasma oxidant levels in goats are higher in the hot season and in the peripartum period and depend on the nutritional regimen and on the production level (Celi et al., 2010; Di Trana et al., 2006). Moreover, observing the total oxidant concentrations shown by the cited papers, ROM levels range from low values (64-83 U. Carr) for the current study to high values (250-280 U. Carr) observed by Celi et al. (2010), almost as much as those listed as physiological values of the human species. Therefore, a thorough study of these parameters is necessary for the assessment of the specific referral range to properly evaluate the oxidative status in ruminants and to prevent oxidative stress, as suggested by Celi (2011). The greater production observed in the SULB group might have contributed to the small and nonsignificant increase in ROM concentration, which in turn may have led to the increased GSH-Px and SOD activities compared with the SUL and HB groups. An association between milk production and oxidative status due to increased cellular metabolism was found by Lohrke et al. (2004) in cows between lactation onset and peak lactation and by Castillo et al. (2006) during early lactation. In the present study, the goats were in midlactation (86 DIM) and the physiologically stressful situation was overcome. From 
Table 4. Least squares means of milk yield, milk quality, milk polyphenol content, and total antioxidant capacity

\begin{tabular}{|c|c|c|c|c|c|}
\hline \multirow[b]{2}{*}{ Item } & \multicolumn{3}{|c|}{ Feeding regimen $(\mathrm{FR})^{1}$} & \multirow[b]{2}{*}{ SEM } & \multirow{2}{*}{$\frac{\text { Significance }}{\text { FR }}$} \\
\hline & HB & SUL & SULB & & \\
\hline Milk yield $(\mathrm{g} / \mathrm{d})$ & $1.423^{\mathrm{b}}$ & $1.353^{\mathrm{c}}$ & $1.664^{\mathrm{a}}$ & 102 & $* * *$ \\
\hline $\operatorname{FPCM}^{2}(\mathrm{~g} / \mathrm{d})$ & $1.340^{\mathrm{b}}$ & $1.388^{\mathrm{b}}$ & $1.618^{\mathrm{a}}$ & 94 & $* * *$ \\
\hline Fat $(\%)$ & $2.95^{\mathrm{c}}$ & $3.59^{\mathrm{a}}$ & $3.17^{\mathrm{b}}$ & 0.14 & *** \\
\hline Lactose (\%) & 4.45 & 4.51 & 4.46 & 0.05 & NS \\
\hline Total protein $(\%)$ & $3.38^{\mathrm{b}}$ & $3.54^{\mathrm{a}}$ & $3.52^{\mathrm{a}}$ & 0.90 & $* * *$ \\
\hline Casein $(\%)$ & $2.61^{\mathrm{b}}$ & $2.69^{\mathrm{a}}$ & $2.73^{\mathrm{a}}$ & 0.09 & $* *$ \\
\hline $\operatorname{Urea}(\mathrm{mg} / \mathrm{dL})$ & $30.9^{\mathrm{b}}$ & $35.4^{\mathrm{a}}$ & $32.1^{\mathrm{b}}$ & 1.49 & *** \\
\hline $\mathrm{MTP}^{3}\left(\mathrm{~g}\right.$ of $\left.\mathrm{GAE}^{4} / \mathrm{d}\right)$ & $0.819^{\mathrm{b}}$ & $0.964^{\mathrm{a}}$ & $1.081^{\mathrm{a}}$ & 0.07 & $*$ \\
\hline MFreeP $^{5}(\mu \mathrm{g} / \mathrm{mL}$ of GAE $)$ & $49.3^{\mathrm{b}}$ & $56.7^{\mathrm{a}}$ & $56.2^{\mathrm{a}}$ & 2.0 & $*$ \\
\hline $\mathrm{WTAC}^{6}(\mathrm{Log} \mu \mathrm{mol} / \mathrm{L})$ & $2.38^{\mathrm{f}}$ & $2.43^{\mathrm{e}}$ & $2.47^{\mathrm{e}}$ & 0.03 & $\dagger$ \\
\hline
\end{tabular}

${ }^{\mathrm{a}-\mathrm{c}}$ Values within a row without a common superscript letter are significantly different $(P \leq 0.05)$.

e,f Values within a row without a common superscript letter are significantly different $(P \leq 0.10)$.

${ }^{1} \mathrm{HB}=$ mixed hay plus $800 \mathrm{~g} / \mathrm{d}$ of barley meal; SUL = sulla fresh forage; SULB = sulla fresh forage plus 800 $\mathrm{g} / \mathrm{d}$ of barley meal.

${ }^{2} \mathrm{FPCM}$ (fat-protein-corrected milk $)=$ milk corrected at $3.5 \%$ fat and $3.5 \%$ protein: $(12.82 \times \mathrm{kg}$ of fat $)+(7.13$

$\times \mathrm{kg}$ of protein $)+(0.323 \times \mathrm{kg}$ of milk $) ;$ Hall, 2004.

${ }^{3} \mathrm{MTP}=$ milk total polyphenols.

${ }^{4} \mathrm{GAE}=$ gallic acid equivalent.

${ }^{5} \mathrm{MFreeP}=$ milk free polyphenols.

${ }^{6} \mathrm{WTAC}=$ total antioxidant capacity in whey.

$\dagger P \leq 0.10 ;{ }^{*} P \leq 0.05 ;{ }^{* *} P \leq 0.01 ;{ }^{* *} P \leq 0.001 ; \mathrm{NS}=$ not significant.

a general perspective, the observations that both the GSH-Px and SOD activities exhibited the same trend exhibited by the ROM are supported by the positive correlation that was detected between the ROM and the SOD $(\mathrm{r}=0.32 ; P<0.05)$. This relationship agrees with findings from goats at pasture (Di Trana et al., 2006) and confirms the specific role of the defensive role of intracellular antioxidants as free radical scavengers.

\section{Metabolic and Hormonal Profiles}

The plasma concentrations of energy metabolism indicators, such as glucose, NEFA, BHBA, and IGF1, are shown in Table 3. Whereas the plasma IGF-1 and urea concentrations were not affected by feeding regimen, our results showed that feeding regimen influenced the NEFA, BHBA $(P \leq 0.01)$, and glucose $(P=$ $0.10)$ concentrations. The SUL group exhibited greater body reserve mobilization compared with the $\mathrm{HB}$ and SULB groups, as indicated by a higher concentration of NEFA (0.389 mmol/L). Given that NEFA concentrations of 0.20 to $0.21 \mathrm{mmol} / \mathrm{L}$ have been suggested for lactating goats at zero net energy balances (Dunshea and Bell, 1989), a higher NEFA level might be linked to a significant increase in NDF intake and to the interesting milk yields from the SUL goats (Table 4). These factors might have induced greater mobilization of body fat. The observations that glucose decreased and NEFA increased in the nonsupplemented goats (SUL) are consistent with observations that have been made of goats at pasture without any supplement during the spring season (Di Trana et al., 2006).

Plasma BHBA increased in the SULB and HB groups compared with the nonsupplemented SUL group. The increased levels of BHBA in the goats that were supplemented with cereals compared with the goats that received no supplement are in accordance with the findings of Fernàndez et al. (2007). The increases in the BHBA levels and reductions in the NEFA levels in the supplemented groups are in agreement with lactation phase (86 DIM) findings that were previously reported by Serment et al. (2011) for midlactation goats that were fed different percentages of concentrates. Furthermore, a positive correlation between BHBA and milk production was found $(\mathrm{r}=0.30 ; P<0.05)$.

\section{Milk}

Milk yields and $35 \mathrm{~g} / \mathrm{kg}$ of FPCM yields were significantly influenced by feeding regimen $(P \leq 0.001$; Table 4). Daily milk yields decreased from the SULB diet to the $\mathrm{HB}$ diet and reached their minimum values with the SUL diet. Moreover, the daily FPCM yield was highest in the SULB diet group, and no difference was detected between the HB and SUL groups.

Productivity was modified by the introduction of the barley supplement into the SUL diet as revealed by comparison to the dry forage plus supplement diet 
(HB). Positive effects of fresh Sulla forage and the nutrient and CT contents of the fresh Sulla forage on milk yields have been detected in both goats (Bonanno et al., 2007a) and sheep (Bonanno et al., 2007b; Molle et al., 2009). According to Roy et al. (2004), the high milk protein secretion observed in Sulla-fed sheep can be attributable to the $\mathrm{CT}$ content that is able to regulate the mammary blood flow, increasing the partitioning of EAA to the mammary gland.

With regard to milk composition (Table 4), only lactose remained unaffected by the feeding system. The milk protein and casein levels were higher $(P \leq 0.05)$ in the fresh Sulla groups (SUL and SULB) than in the HB group. These results are most likely attributable to the increased intakes of CT in the SUL and SULB groups (Table 4) and agree with a result that was previously reported by Bonanno et al. (2013) regarding casein fractions. Indeed, $\mathrm{CT}$ in moderate amounts reduces the degradability of proteins in the rumen, which induces greater absorption of amino acids by the gut (Min et al., 2003) and exerts an anthelmintic action (Hoste et al., 2006); these synergistic actions improve the efficiency of the utilization of dietary protein for milk protein synthesis.

Fat content was significantly higher $(P \leq 0.05)$ in the SUL groups than in the other groups. The increase in milk fat in the SUL group was most likely attributable to the highest level of NDF intake (Table 2) and lowest milk yield that were observed in this group.

Concerning milk urea content, our results showed that urea concentrations were affected by feeding regimen $(P \leq 0.001)$. The increase in milk urea observed in the SUL group was a consequence of the higher CP intake of this group (Table 2) compared with those of the other groups. Milk urea nitrogen is closely related to dietary $\mathrm{CP}$ concentration and $\mathrm{CP}$ intake (Bonanno et al., 2010). The SUL group also exhibited a slight increase in plasma urea concentration (Table 3), which originated from the unbalanced energy-to-protein ratio of the diet and resulted in lower rumen microbial growth and higher levels of nitrogen waste (Harmeyer and Martens, 1980). These observations are supported by the well-known relationship between blood and milk urea contents $(\mathrm{r}=0.63 ; P<0.01)$.

Regarding the effects of feeding regimen, the results revealed that the milk from the SULB- and SUL-fed goats exhibited higher WTAC $(P \leq 0.10)$, milk total polyphenol $(P \leq 0.05)$, and MFreeP $(P \leq 0.05)$ values than did the milk from the HB-fed goat samples, whereas no differences between the SULB- and SUL-fed groups were observed (Table 4 ). These results are supported by the daily total polyphenol intakes of the goats that were fed the SULB or SUL diets (Table 2) because of the total phenolic substances in the Sulla forage, particularly the leaf blades and flowers, which have the highest phenolic substance contents (Piluzza and Bullitta, 2010). These observations are also supported by the concomitant increases in PTP and PFreeP in the SULB and SUL groups (Table 3) and by the positive correlation that was observed between PFreeP and milk TP $(\mathrm{r}=0.38 ; P=0.031)$, which suggests relationships between intake levels and blood and milk concentrations of TP. These results led us to hypothesize that polyphenols from ingested Sulla are positively transferred to the milk through the bloodstream. Furthermore, the positive correlation between MFreeP content and WTAC value $(\mathrm{r}=0.42 ; P=0.018)$ highlights the role of free polyphenols in determining the antioxidant activity of the milk.

Our results showed that the TP content of the diet can affect the antioxidant activities and polyphenol contents of goat milk. Similarly, some studies have reported similar findings regarding milk quality (De Feo et al., 2006; Jordán et al., 2010), milk products (Hilario et al., 2010), and meat (Moñino et al., 2008; Luciano et al., 2011) in small ruminants. Specifically, De Feo et al. (2006) reported positive relationships between forage intake and antioxidant compounds, mainly flavonoids such as rutin and quercetin, in goat milk. Sepe et al. (2011) detected simple phenols in the milk, cheese, and whey of goats fed Avena sativa. According to Hilario et al. (2010), grazing management or fresh forage represent the best options for producing healthy profiles of bioactive compounds in dairy products.

These findings highlight the effectiveness of Sulla fresh forage diets for goats; these diets improve the plasma oxidative statuses and the total antioxidant capacities of milk. Therefore, the present study showed that goats with high levels of total polyphenol intake exhibit high levels of total polyphenols in their plasma and milk. In conclusion, Sulla fresh forage exerts antioxidant activities due to its secondary compounds, which provide additional value in terms of oxidative status, and Sulla fresh forage seems to be a promising strategy for improving product quality.

\section{ACKNOWLEDGMENTS}

This research was supported by the Italian Ministry of Education, University and Research (MIUR, Rome; Project of High National Interest PRIN 2007B4JBWN_003).

\section{REFERENCES}

Addis, M., A. Cabiddu, G. Pinna, M. Decandia, G. Piredda, A. Pirisi, and G. Molle. 2005. Milk and cheese fatty acid composition in sheep fed Mediterranean forages with reference to conjugated linoleic acid cis9,trans11. J. Dairy Sci. 88:3443-3454. 
Amato, G., G. Di Miceli, D. Giambalvo, C. Scarpello, and L. Stringi. 2005. Condensed tannins content in sulla (Hedysarum coronarium L.) as affected by environment, genotype and growth stage. Pages 41-54 in Bioactive Compounds in Pasture Species for Phytotherapy and Animal Welfare. S. Bullitta, ed. Consiglio Nazionale delle Ricerche Istituto per il Sistema Produzione Animale in Ambiente Mediterraneo, Sassari, Italy.

Ames, B. N., M. K. Shigenaga, and T. M. Hagen. 1995. Mitochondrial decay in aging. Biochim. Biophys. Acta 1271:165-170.

AOAC. 1995. Official Methods of Analysis. 16th ed. Assoc. Off. Anal. Chem., Washington, DC.

Avondo, M., L. Biondi, R. I. Pagano, A. Bonanno, and L. Lutri. 2008. Feed intake. Pages 147-160 in Dairy Goats Feeding and Nutrition. A. Cannas, and G. Pulina, ed. CABI Publishing, Wallingford, UK.

Bendich, A. 1993. Physiological role of antioxidants in the immune system. J. Dairy Sci. 76:2789-2794.

Benzie, I. F. F., and J. J. Strain. 1996. The ferric reducing ability of plasma (FRAP) as a measure of "antioxidant power": The FRAP assay. Anal. Biochem. 239:70-76.

Bhat, T. K., B. Singh, and O. P. Sharma. 1998. Microbial degradation of tannins-A current perspective. Biodegradation 9:343-357.

Bonanno, A., A. Di Grigoli, M. Montalbano, V. Bellina, F. Mazza, and M. Todaro. 2013. Effects of diet on casein and fatty acid profiles of milk from goats differing in genotype for $\alpha \mathrm{S} 1$-casein synthesis. Eur. Food Res. Technol. 237:951-963.

Bonanno, A., A. Di Grigoli, L. Stringi, G. Di Miceli, D. Giambalvo, G. Tornambè, D. Vargetto, and M. L. Alicata. 2007b. Intake and milk production of goats grazing Sulla forage under different stocking rates. Ital. J. Anim. Sci. 6(Suppl. 1):605-607.

Bonanno, A., G. Di Miceli, A. Di Grigoli, A. S. Frenda, G. Tornambè, D. Giambalvo, and G. Amato. 2011. Effects of feeding green forage of sulla (Hedysarum coronarium L.) on lamb growth and carcass and meat quality. Animal 5:148-154. http://dx.doi.org/10.1017/ S1751731110001576.

Bonanno, A., A. Di Grigoli, D. Vargetto, G. Tornambè, G. Di Miceli, and D. Giambalvo. 2007a. Grazing sulla and/or ryegrass forage for 8 or 24 hours daily. Effects on ewes feeding behaviour. Pages in 208-211 in Permanent and Temporary Grassland Plant, Environment and Economy. European Grassland Federation. A. De Vliegher, and L. Carlier, ed. ILVO, Merelbeke, Belgium.

Bonanno, A., M. Todaro, A. Di Grigoli, M. L. Scatassa, G. Tornambè, and M. L. Alicata. 2010. Relationships between dietary factors and milk urea nitrogen level in goats grazing herbaceous pasture. Ital. J. Anim. Sci. 7:219-235.

Burke, J. L., G. C. Waghorn, W. C. McNabb, and I. M. Brookes. 2004. The potential of sulla in pasture-based system. Anim. Prod. Aust. 25:25-28.

Cabiddu, A., G. Molle, M. Decandia, S. Spada, M. Fiori, G. Piredda, and M. Addis. 2009. Responses to condensed tannins of flowering sulla (Hedysarum coronarium L.) grazed by dairy sheep. Part 2: Effects on milk fatty acid profile. Livest. Sci. 123:230-240.

Castillo, C., J. Hernandez, I. Valverde, V. Pereira, J. Sotillo, M. L. Alonso, and J. L. Benedito. 2006. Plasma malonaldehyde (MDA) and total antioxidant status (TAS) during lactation in dairy cows. Res. Vet. Sci. 80:133-139.

Celi, P. 2011. Oxidative stress in ruminants. Pages 191-231 in Studies on Veterinary Medicine, Oxidative Stress in Applied Basic Research and Clinical Practice 5. L. Mandelker, and P. Vajdovich, ed. Humana Press/Springer Science + Business Media LLC, New York, NY.

Celi, P., and H. W. Raadsma. 2010. The effects of Yerba Mate (Ilex paraguarensis) supplementation on the productive performance of lactating dairy cows. Anim. Prod. Sci. 50:339-344.

Celi, P., and A. Robinson. 2010. Effects of Yerba Mate (Ilex paraguarensis) supplementation on performances of dairy calves. Anim. Prod. Sci. 50:376-381.

Celi, P., A. Di Trana, and S. Claps. 2010. Effects of plane of nutrition on oxidative stress in goats during the peripartum period. Vet. J. 184:95-99.

Cesarone, M. R., G. Belcaro, M. Carratelli, U. Cornelli, M. T. De Sanctis, L. Incandela, A. Barsotti, R. Terranova, and A. Nico- laides. 1999. A simple test to monitor oxidative stress. Int. Angiol. 18:127-130.

Chen, J., H. Lindmark-Månssona, L. Gortonc, and B. Akesson. 2003. Antioxidant capacity of bovine milk as assayed by spectrophotometric and amperometric methods. Int. Dairy J. 13:927-935.

De Feo, V., E. Quaranta, V. Fedele, S. Claps, R. Rubino, and C. Pizza. 2006. Flavonoids and terpenoids in goats milk in relation to forage intake. Ital. J. Food Sci. 18:85-92.

Di Trana, A., P. Celi, S. Claps, V. Fedele, and R. Rubino. 2006. The effect of hot season and nutrition on the oxidative status and metabolic profile in dairy goats during mid lactation. Anim. Sci. $82: 717-722$.

Dohi, K., K. Satoh, H. Ohtaki, S. Shioda, Y. Miyake, M. Shindo, and T. Aruga. 2005. Elevated plasma levels of bilirubin in patients with neurotrauma reflect its pathophysiological role in free radical scavenging. In Vivo 19:855-860.

Dunshea, F. R., and A. W. Bell. 1989. Relations between plasma nonesterified fatty acid metabolism and body fat mobilization in primiparous lactating goats. Br. J. Nutr. 62:51-61.

FAO/IAEA. 2000. Quantification of tannins in tree foliage. Working Document, IAEA, Vienna, Austria.

Fernàndez, J. R., E. Ramos, G. De la Torre, R. Hermoso, F. Gil Extremera, and M. R. Sanz Sampelayo. 2007. Blood metabolites as indicators of energy status in goats. Options Méditer. Sér. A $74: 451-455$

Gabai, G., S. Testoni, R. Piccinini, L. Marinelli, and G. Stradaioli. 2004. Oxidative stress in primiparous cows in relation to dietary starch and the progress of lactation. Anim. Sci. 79:99-108.

Gladine, C., E. Rock, C. Morand, D. Bauchart, and D. Durand. 2007. Bioavailability and antioxidant capacity of plant extracts rich in polyphenols, given as a single acute dose, in sheep made highly susceptible to lipoperoxidation. Br. J. Nutr. 98:691-701.

Hagerman, A. E., K. M. Riedl, G. A. Jones, N. Sovik, N. T. Ritchard, P. W. Hartzfeld, and T. L. Riechel. 1998. High molecular weight plant polyphenolics (tannins) as biological antioxidants. J. Agric. Food Chem. 46:1887-1892.

Hall, M. B. 2004. Using feed efficiency as a ration evaluation and nutrient management tool. Adv. Dairy Technol. 16:29-36.

Harmeyer, J., and H. Martens. 1980. Aspects of urea metabolism in ruminants with reference to the goat. J. Dairy Sci. 63:1707-1728.

Hilario, M. C., C. D. Puga, A. N. Ocaña, and F. P. G. Romo. 2010. Antioxidant activity, bioactive polyphenols in Mexican goats' milk cheeses on summer grazing. J. Dairy Res. 77:20-26. http:// dx.doi.org/10.1017/S0022029909990161.

Hoste, H., F. Jackson, S. Athanasiadou, S. M. Thamsborg, and S. O. Hoskin. 2006. The effects of tannin-rich plants on parasitic nematodes in ruminants. Trends Parasitol. 22:253-261.

ISO. 2005. Determination of substances characteristic of green and black tea. Part 1: Content of total polyphenols in tea. Colorimetric method using Folin-Ciocalteu reagent. vol. ISO 14502-1. International Organization for Standardization (ISO), Geneva, Switzerland.

Jordán, M. J., M. I. Moñino, C. Martìnez, A. Lafuente, and J. A. Sotomayor. 2010. Introduction of distillate rosemary leaves into the diet of the murciano-granadina goat: Transfer of polyphenolic compounds to goats' milk and the plasma of suckling goat kids. J. Agric. Food Chem. 58:8265-8270. http://dx.doi.org/10.1021/ jf100921z.

Larraín, R. E., M. P. Richards, D. M. Schaefer, L. L. Ji, and J. D. Reed. 2007. Growth performance and muscle oxidation in rats fed increasing amounts of high-tannin sorghum. J. Anim. Sci. 85:3276-3284.

Lohrke, B., T. Viergutz, W. Kanitz, K. Gollnitz, F. Becker, A. Hurtienne, and F. J. Schweigert. 2004. High milk yield in dairy cows associated with oxidant stress. Online J. Vet. Res. 8:70-78.

López-Andrés, P., G. Luciano, V. Vasta, T. M. Gibson, L. Biondi, A. Priolo, and I. Mueller-Harvey. 2013. Dietary quebracho tannins are not absorbed, but increase the antioxidant capacity of liver and plasma in sheep. Br. J. Nutr. 110:632-639. http://dx.doi. org/10.1017/S0007114512005703. 
Luciano, G., V. Vasta, F. J. Monahan, P. Lòpez-Andréz, L. Biondi, M. Lanza, and A. Priolo. 2011. Antioxidant status, colour stability and myoglobin resistance to oxidation of longissimus dorsi muscle from lambs fed a tannin-containing diet. Food Chem. 124:10361042.

Machín, M. M., F. Simoyi, K. P. Blemings, and H. Klandorf. 2004. Increased dietary protein elevates plasma uric acid and is associated with decreased oxidative stress in rapidly-growing broilers. Comp. Biochem. Physiol. B Biochem. Mol. Biol. 137:383-390.

Makkar, H. P. S., K. Becker, H. J. Abel, and C. Szegletti. 1995. Degradation of condensed tannins by rumen microbes exposed to quebracho tannins (QT) in rumen simulation technique (RUSITEC) and effects of QT on fermentative processes in the RUSITEC. J. Sci. Food Agric. 69:495-500.

Makkar, H. P. S., G. Francis, and K. Becker. 2007. Bioactivity of phytochemicals in some lesser known plants and their effects and potential applications in livestock and aquaculture production systems. Animal 1:1371-1391.

Marshall, T. A., and R. J. Roberts. 1990. In vitro and in vivo assessment of lipid peroxidation of infant nutrient preparations: Effect of nutrition on oxygen toxicity. J. Am. Coll. Nutr. 9:190-199.

Miller, J. K., E. Brzezinska-Slebodzinska, and F. C. Madsen. 1993 Oxidative stress, antioxidants, and animal function. J. Dairy Sci. 76:2812-2823.

Min, B. R., T. N. Barry, G. T. Attwood, and W. C. McNabb. 2003. The effect of condensed tannins on the nutrition and health of ruminants feed fresh temperate forages: A review. Anim. Feed Sci. Technol. 106:3-19.

Molle, G., M. Decandia, A. Cabiddu, S. Y. Landau, and A. Cannas. 2008. An update of the nutrition of dairy sheep grazing Mediterranean pastures. Small Rumin. Res. 77:93-112.

Molle, G., M. Decandia, N. Fois, S. Ligios, A. Cabiddu, and M. Sitzia 2003. The performance of Mediterranean dairy sheep given access to sulla (Hedysarum coronarium L.) and annual ryegrass (Lolium rigidum Gaudin) pastures in different time proportions. Small Rumin. Res. 49:319-328.

Molle, G., M. Decandia, V. Giovannetti, A. Cabiddu, N. Fois, and M. Sitzia. 2009. Responses to condensed tannins of flowering sulla (Hedysarum coronarium L.) grazed by dairy sheep. Part 1: Effects on feeding behaviour, intake, diet digestibility and performance. Livest. Sci. 123:138-146.

Moñino, I., C. Martìnez, J. A. Sotomayor, A. Lafuente, and M. J. Jordàn. 2008. Polyphenolic transmission to Segureño lamb meat from ewes diet supplemented with the distillate from rosemary (Rosmarinus officinalis) leaves. J. Agric. Food Chem. 56:33633367.

Nieto, G., P. Díaz, S. Bañón, and M. D. Garrido. 2010. Diatery administration of ewe diets with a distillate from rosemary leaves (Rosmarinus officinalis L.): Influence on lamb meat quality. Meat Sci. 84:23-29.

Pedernera, M., P. Celi, S. C. García, H. E. Salvin, I. Barchia, and W. J. Fulkerson. 2010. Effect of diet, energy balance and milk production on oxidative stress in early-lactating dairy cows grazing pasture. Vet. J. 186:352-357. http://dx.doi.org/10.1016/j. tvjl.2009.09.003.
Perez-Maldonado, R. A., and B. W. Norton. 1996. Digestion of 14Clabelled condensed tannins from Desmodium intortum in sheep and goats. Br. J. Nutr. 76:501-513.

Petzke, K. J., A. Elsner, J. Proll, F. Thielecke, and C. C. Metges. 2000. Long-term high protein intake does not increase oxidative stress in rats. J. Nutr. 130:2889-2896.

Piluzza, G., and S. Bullitta. 2010. The dynamics of phenolic concentration in some pasture species and implications for animal husbandry. J. Sci. Food Agric. 90:1452-1459.

Porter, L. J., L. N. Hrstick, and B. G. Chan. 1986. The conversion of procyanidins and prodelphinidins to cyniadin and delphinidin. Phytochemistry 25:223-230.

Riedl, K. M., and A. E. Hagerman. 2001. Tannin-protein complexes as radical scavengers and radical sinks. J. Agric. Food Chem. 49:4917-4923.

Roy, N. C., B. R. Sinclair, B. Treloar, W. C. McNabb, J. Peters, M. Tavendale, and A. Kirk. 2004. The effects of condensed tannins in Sulla (Hedysarum coronarium) on valine kinetics in the ovine mammary gland. Anim. Prod. Aust. 25:148-151.

Santiago-Arteche, R., P. Muňiz, M. Cavia-Saiz, C. Garcia-Giron, M. Garcia-Gonzalez, B. Llorente-Ayala, and M. J. Coma-del Corral. 2012. Cancer chemotherapy reduces plasma total polyphenols and total antioxidants capacity in colorectal cancer patients. Mol. Biol. Rep. 39:9355-9360.

Santucci, P. M., A. Branca, M. Napoleone, R. Bouche, G. Aumont, F Poisot, and G. Alexandre. 1991. Body condition scoring of goats in extensive conditions. Pages $240-256$ in Goat Nutrition. P. Morand-Fehr, ed. EAAP Publication, Pudoc III, Wageningen, The Netherlands.

Sepe, L., A. Cornu, B. Graulet, S. Claps, and D. Rufrano. 2011. Phenolic content of forage, milk, whey and cheese from goats fed $A v$ ena sativa. Pages 31-32 in Proc. 10th Int. Meeting on Mountain Cheese, Dronero, CN, Italy. University of Turi, Turin, Italy.

Serafini, M., G. Maiani, and A. Ferro-Luzzi. 1998. Alcohol-free red wine enhances plasma antioxidant capacity in humans. J. Nutr. 128:1003-1007.

Serment, A., P. Schmidely, S. Giger-Reverdin, P. Chapoutot, and D. Sauvant. 2011. Effects of the percentage of concentrate on rumen fermentation, nutrient digestibility, plasma metabolites, and milk composition in mid-lactation goats. J. Dairy Sci. 94:3960-3972.

Tava, A., M. G. De Benedetto, D. Tedesco, G. Di Miceli, and G. Piluzza. 2005. Proanthocyanidins from Hedysarum, Lotus and Onobrychis spp. growing in Sardinia and Sicily and their antioxidant activity. Page 271 in Proc. 20th Int. Grassland Congr, Dublin, Ireland. Wageningen Academic Publishers, Wageningen, The Netherlands.

Terrill, T. H., G. C. Waghorn, D. J. Woolley, W. C. Nabb, and T. N Barry. 1994. Assay and digestion of 14C-labelled condensed tannins in the gastrointestinal tract of sheep. Br. J. Nutr. 72:467-477.

Van Soest, P. J., J. B. Robertson, and B. A. Lewis. 1991. Methods for dietary fiber, neutral detergent fiber, and non-starch polysaccharides in relation to animal nutrition. J. Dairy Sci. 74:3583-3597. 